УДК 657:339.331.2

(C) 2014

Дорогань-Писаренко Л. О., кандидат економічних наук

Полтавська державна аграрна академія

\title{
ОПЛАТА ПРАЦІ ДЕРЖАВНИХ СЛУЖБОВЦІВ: ОРГАНІЗАЦИИНО-ОБЛІКОВИЙ АСПЕКТ
}

\section{Рецензент - доктор економічних наук, професор В. Я. Плаксієнко}

У статті висвітлено сучасний стан оплати праці державних службовиів. Проаналізовано досвід зарубіжних краӥн з організації державної служби. Запропоновано врегулювати систему оплати державних службовиів шляхом реформування структури їх доходу. Визначено необхідність уніфікації різниці в окладах і заробітних платах службовиів різних рівнів виконавчої влади. Визначено основні напрями удосконалення організації праці державних службовців та ї̈ оплати.

Ключові слова: державна служба, модель державної служби, оподаткування, оплата праиі, преміювання.

Постановка проблеми. Система бухгалтерського обліку, зокрема праці та іiі оплати, перебуває в процесі реформування відповідно до міжнародних стандартів і нині ще недосконала. Значною мірою це пов'язано з тим, що праця як об'єкт обліку є однією з найскладніших і найвагоміших економічних категорій, оскільки покликана виконувати життєво необхідні для людини відтворювальну, регулюючу, стимулюючу та соціальну функції.

Проблема удосконалення оплати праці є вузловою в системі соціально-економічних відносин не тільки тому, що торкається інтересів основної частини населення країни, але й у зв'язку 3 тим, що впливає на всі параметри ринку: через механізми попиту та пропозиції - на структуру виробництва і його динаміку; через конкуренцію між працею та капіталом - на технологічний рівень виробництва і його ефективність; на якість робочої сили; на рівень зайнятості; динаміку цін і інфляцію.

Фінансування оплати праці державних службовців у бюджетних установах здійснюється за захищеною статтею видатків «Оплата праці працівників бюджетних установ» (код 2110), яка має найбільшу питому вагу в кошторисах і сягає 70-80 \% загальних асигнувань на видатки.

Аналіз останніх досліджень і публікацій, у яких започатковано розв'язання проблеми. Дослідженню актуальних питань реформування та удосконалення організації оплати праці державних службовців надають увагу такі вітчизня- ні науковці як С. Дубенко, А. М. Колот, І. Г. Пахомова, В. Філіпповський. Проблеми облікового відображення праці держаних службовців та іiі оплати в своїх працях висвітлювали вчені та практики: П. Й. Атамас, А. О. Заїнчковський, С. В. Свірко, О. О. Чечуліна та інші.

Водночас вітчизняні системи бюджетного обліку, державної служби та окремі іiі елементи, насамперед оплата праці державних службовців, не $\epsilon$ ідеальними й вимагають реформування, що підтверджує актуальність і обумовлює необхідність подальших досліджень.

Мета досліджень: висвітлення особливостей праці державних службовців та ії оплати; обгрунтування необхідності удосконалення та визначення основних напрямів реформування оплати праці в бюджетних установах та шляхів поліпшення системи оплати праці.

Результати досліджень. Оплата праці - це складне багатовимірне економічне явище, яке відображає взаємодію багатьох економічних процесів, будучи важливим елементом суспільного відтворення й розвитку системи ринкових відносин.

Як моральна категорія оплата праці покликана забезпечити гідний рівень життя населення. Проте базовим макропоказником економічного та соціального розвитку держави $є$ частка фонду оплати праці працівників у структурі ВВП, який у розвинених країнах становить від 60 (країни ЄС) до $75 \%$ (США) [5]. У 2013 р. уряд України залишив цю частку на рівні 30,6 \% (у 1990 році $57 \%$ ). Якщо ж враховувати рівень тінізації економіки, то реально фонд оплати праці $\epsilon$ ще меншим [4].

Очевидно, що рівень оплати праці в Україні істотно відстає від загальносвітових норм. Як економічна категорія заробітна плата не повною мірою виконує свої функції - розподільчу, відтворення робочої сили, стимулювання праці. Нині вона фактично перетворилася на один із варіантів соціальної допомоги, який мало залежить від результатів праці. Особливо гострою ця проблема є для такого сегмента ринку праці, як державна служба, де майже відсутній зв'язок 


\section{EKOHOMIKA}

рівня оплати праці з ії результатами.

Наразі в Україні існує дві паралельні системи оплати праці працівників бюджетної сфери: одна заснована на дії Єдиної тарифної сітки, а інша регульована спеціальними нормативно-правовими актами, які відносяться до спеціального законодавства, що регулює оплату праці окремих категорій працівників (державні службовці, судді, працівники правоохоронних органів, прокурорські працівники тощо) [7].

Основними функціями та завданням оплати праці державних службовців в Україні є: мотивація працівників до виконання посадових обов'язків із максимальним використанням їх здібностей і вмінь; забезпечення внутрішньої (всередині системи державної служби) та зовнішньої (у контексті оплати праці в державі) рівності; добір кваліфікованих кадрів і забезпечення прийнятного рівня їх плинності; утримання кваліфікованих кадрів; відповідність до вимог чинного законодавства тощо.

Iз цього приводу варто згадати, що Законом України «Про державну службу» [2] передбачено, що оплата праці державних службовців повинна забезпечувати достатні матеріальні умови для незалежного виконання службових обов'язків, сприяти укомплектуванню органів державної влади компетентними і досвідченими кадрами, стимулювати їх сумлінну та ініціативну працю.

В умовах сьогодення ані сама система, ані рівень оплати праці державних службовців в Україні не забезпечують виконання цих завдань. Оплата праці державних службовців досить слабо пов'язана 3 кваліфікацією кадрів, освітою та професійною підготовкою, результатами навчання, складністю й відповідальністю трудових функцій державного службовця, ефективністю виконання структурами влади та їх апаратами функцій держави.

У сучасній науковій літературі виділяються декілька основних моделей організації державної служби, зокрема «американська» та «європейська», до якої відносять досвід країн Великобританії, Франції, Німеччини. Зауважимо, що сучасні риси організації державної служби в «європейській» моделі залежно від країни дещо відрізняються.

У «американській» моделі державна служба розглядається як рівноправний вид діяльності на ринку праці. Під час прийому на роботу враховуються, передусім, ділові та професійні якості. Державний службовець працює за контрактом без особливих привілеїв і соціальних преференцій, які зумовлені належністю до відповідної категорії державних службовців, вислугою років та іншими атрибутами європейської бюрократичної моделі - про ступінь успішності чиновника судять за ефективністю його роботи [4].

Однією з основних рис існуючої сьогодні моделі державної служби в США $є$ наявність «системи заслуг» і залежність оплати праці й просування по службі від результатів роботи державного службовця. Заміщення посад державної служби, заснованої на «системі заслуг», проводиться у двох формах - «відкритої» (найпоширенішої) і «закритої». При відкритому наборі посада може бути зайнята будь-якою особою, яка успішно здала іспит, а при закритому, як правило, - тільки в порядку кар'єрної служби в даній системі. Закритий набір передбачений для комплектування вищих посад державного апарату (міністрів, їхніх заступників і помічників) i низки міністерств і відомств (Державного департаменту, ФБР, ЦРУ, служб охорони здоров'я й лісового господарства).

У Великобританії адміністративна реформа М. Тетчер зі скорочення витрат міністерств і відомств поділила всі урядові установи на центри формування політики й установи, що виконують рішення (квазіадміністративні неурядові організації (QUANGO)). При цьому державна служба як така була збережена лише для центрів формування політики [3]. Чиновнику, який прийнятий на державну службу, гарантується за будь-яких умов добре оплачувана робота, пакет соціальних пільг і досить високий рівень пенсійного забезпечення. Таким чином, державний службовець свідомо отримує не надто високу, проте гарантовану матеріальну стабільність. У Франції існує висока елітарність державної служби, розвинена система гарантій правової й соціальної захищеності службовця та досить ускладнена процедура його звільнення.

Модель організації державної служби в Україні за характеристикою системи оплати праці тяжіє до «європейської», водночас вона має й певні відмінності як стосовно рівня оплати праці, так і питомої ваги посадового окладу у структурі заробітної плати державного службовця (табл. 1). Дані таблиці 1 підтверджують частку посадового окладу в структурі фонду оплати праці службовця як домінуючої фінансової складової в розмірі $27 \%$, окрім того премія займає $15,8 \%$, надбавки за Постановою КМУ «Про упорядкування структури та умов оплати праці працівників апарату органів виконавчої влади, органів прокуратури, судів та інших органів» № 268 від 09.03.2006 р. (за вчене звання і науковий ступінь, надбавку за високі досягнення у праці або за виконання особливо важливої роботи, 


\section{EKOHOMIKA}

службовцям - у розмірі близько $50 \%$ посадового окладу з урахуванням надбавки за вислугу років тощо) становить 13,0-13,8 \%. Із 20 працюючих осіб 18 мають статус державного службовця. Крім того, за статтею 2110 «Оплата праці» передбачено фінансування виплати «лікарняних» за рахунок установи. У грудні 2013 р. серед держаних службовців така виплата становила близько $1,1 \%$, а в цілому по установі - 1,3\%.

Оплата праці державних службовців в Україні суттєво відстає від світових стандартів. Так, згідно 3 міжнародними стандартами, для країн Центральної і Східної Європи та СНД введено міжнародний критерій бідності. У відповідності 3 критеріями Світового банку, бідними вважаються особи, в яких вартість добового споживання становить 4,3 долара США (в обрахунку за паритетом купівельної спроможності). Для порівняння: для країн із розвинутою ринковою економікою критерій бідності - це вартість добового споживання в розмірі 14,46 доларів США. За цим критерієм в Україні до категорії бідних на- лежать 26,7 \% населення, 14,7 \% проживає злиденно. Близько половини населення країни $(46,8 \%)$ вважає себе бідними [6].

Важливо враховувати також те, що особливості вітчизняної державної служби й певні обмеження та заборони, пов'язані з прийняттям і проходженням державної служби (відповідно до законів України «Про державну службу» (ст. 13, 16) [2], не дозволяють державним службовцям збільшити свої доходи шляхом комерційної діяльності: їм заборонено займатися підприємницькою діяльністю, брати участь в управлінні комерційними структурами, виконувати іншу оплачувану роботу на умовах сумісництва, крім педагогічної, наукової та іншої творчої діяльності. Тому заробітна плата державних службовців $\epsilon$ практично єдиним джерелом їх доходів.

Преміювання керівників установ та їх заступників, встановлення їм надбавок і доплат до посадових окладів, надання матеріальної допомоги здійснюється за рішенням органу вищого рівня у межах наявних коштів на оплату праці.

Розиифровка структури видатків за статтею «Оплата праці» Управління Пенсійного фонду Украйни в Оржицькому районі (в розрахунку на штатну чисельність працюючих 20 осіб, із яких 18 - державні службовці), 2013 р.

\begin{tabular}{|c|c|c|c|c|c|c|}
\hline & \multicolumn{6}{|c|}{ Разом працівників } \\
\cline { 2 - 7 } Показники & $\begin{array}{c}\text { чисель- } \\
\text { ність, } \\
\text { осіб }\end{array}$ & $\begin{array}{c}\text { суда } \\
\text { видатку, } \\
\text { грн }\end{array}$ & $\begin{array}{c}\text { питома вага } \\
\text { показника у } \\
\text { фонді опла- } \\
\text { ти праці, \% }\end{array}$ & $\begin{array}{c}\text { чисель- } \\
\text { ність, } \\
\text { осіб }\end{array}$ & $\begin{array}{c}\text { сума } \\
\text { видатку, } \\
\text { грн }\end{array}$ & $\begin{array}{c}\text { питомаза вага } \\
\text { фонді опла- } \\
\text { ти праці, \% }\end{array}$ \\
\hline Фонд у посадових окладах & 20 & 168928,70 & 27,0 & 18 & 155853,15 & 26,9 \\
\hline Надбавка за ранг & 18 & 8198,85 & 1,3 & 18 & 8198,85 & 1,4 \\
\hline Надбавка за вислугу років & 19 & 40434,50 & 6,5 & 17 & 37819,38 & 6,5 \\
\hline $\begin{array}{c}\text { Надбавка по постанові КМУ } \\
\text { № 268 * }\end{array}$ & 20 & 81581,79 & 13,0 & 18 & 80012,72 & 13,8 \\
\hline Премія & 20 & 99116,11 & 15,8 & 18 & 91859,24 & 15,8 \\
\hline $\begin{array}{c}\text { Матеріальна допомога } \\
\text { на оздоровлення }\end{array}$ & 17 & 54671,80 & 8,7 & 15 & 49737,65 & 8,6 \\
\hline $\begin{array}{c}\text { Матеріальна допомога } \\
\text { на вирішення соціально- } \\
\text { побутових питань }\end{array}$ & 1 & 2000,00 & 0,3 & 1 & 2000,00 & 0,3 \\
\hline $\begin{array}{c}\text { Індексація } \\
\text { Разом фонд оплати праці }\end{array}$ & 18 & 65483,88 & 10,5 & 16 & 59297,90 & 10,2 \\
\hline $\begin{array}{c}\text { Крім того, виплата } \\
\text { по тимчасовій непраце- } \\
\text { здатності (КЕКВ 2110) ** }\end{array}$ & 9 & 818425,84 & 98,9 & 18 & 573925,50 & 98,9 \\
\hline $\begin{array}{c}\text { Всього фонд оплати праці } \\
\text { по КЕКВ 2110 }\end{array}$ & 20 & 625500,00 & 100,0 & 18 & 580056,39 & 100,0 \\
\hline
\end{tabular}

Примітка: * - Постанова КМУ «Про упорядкування структури та умов оплати праці працівників апарату органів виконавчої влади, органів прокуратури, судів та інших органів» № 268 від 09.03.2006 р.

** - допомога 3 тимчасової втрати працездатності за перші 5 днів, що виплачується установою за рахунок інкасування за кодом 2110. 


\section{EKOHOMIKA}

Керівники закладів та установ за погодженням i3 профспілковими комітетами затверджують положення про преміювання працівників. Розмір премії працівника залежить від особистого внеску в загальні результати роботи підрозділу, закладу і граничними розмірами не обмежується. Розрахунок премії в Управлінні Пенсійного фонду розраховується в розмірі 50 \% від фактично нарахованої оплати праці.

При зарахуванні на роботу державним службовцям присвоюється відповідний ранг у межах категорії. Щомісячно виплачується надбавка за вислугу років, яка встановлюється у відсотках до посадового окладу з урахуванням плати за ранг, залежно від стажу державної служби: понад 3 роки - $10 \%$; понад 5 років - $15 \%$; понад 10 років - $20 \%$; понад 15 років - $25 \%$; понад 20 років - $30 \%$; понад 25 років - $40 \%$.

У разі, коли величина індексу споживчих цін, обчисленого наростаючим підсумком, перевищить поріг індексації, установлений у розмірі $101 \%,-$ проводиться індексація грошових доходів працівників. Індексації підлягають грошові доходи населення в межах прожиткового мінімуму, установленого для відповідних соціальних i демографічних груп населення; частина грошових доходів, що не перевищує прожитковий мінімум, індексації не підлягає. Сума індексації визначається як результат множення грошового доходу, що підлягає індексації, на величину приросту індексу споживчих цін, поділеного на 100. Доходи базового місяця не індексуються. Базовим вважається місяць: прийняття працівника на роботу; підвищення доходу (за умови, що сума такого підвищення більша від суми індексації цього місяця).

У бюджетних організаціях заробітна плата підвищується одночасно всім або майже всім працівникам, згідно з Постановою КМУ і відомчими наказами. Тому й величину приросту індексу споживчих цін для індексації застосовують одну для всіх. Тільки для новоприйнятих працівників і тих, у кого підвищення заробітної плати відбулося в індивідуальному порядку, приріст індексу споживчих цін для проведення індексації буде іншим.

Допомога 3 тимчасової непрацездатності надається застрахованій особі у формі матеріального забезпечення, яка повністю або частково компенсує втрату заробітної плати (доходу), у разі настання у неї страхового випадку.

Основами законодавства України про загальнообов'язкове державне соціальне страхування визначено принципи, а також правові, фінансові й організаційні основи загальнообов'язкового державного соціального страхування громадян в Україні [6]. Так, із доходу державного службовця утримують єдиний соціальний внесок (далі ЄCB) у розмірі $6,1 \%$.

Розділ IV «Податок на доходи фізичних осіб» Податкового кодексу України [5] визначає порядок утримання податку на доходи фізичних осіб (15\% і 17 \%). У разі якщо загальна сума доходів (отриманих державним службовцем у звітному податковому місяці) перевищує десятикратний розмір мінімальної заробітної плати, встановленої законом на 1 січня звітного податкового року, ставка податку становить 17 \% суми перевищення 3 урахуванням податку, сплаченого за ставкою $15 \%$. Сума податку розраховується із заробітної плати за мінусом ССВ та податкової соціальної пільги (далі - ПСП).

Загальний розмір ПСП, на який може розраховувати будь-який платник податку, дорівнює $50 \%$ однієї мінімальної заробітної плати (у розрахунку на місяць), встановленої законом на 1 січня звітного податкового року.

Відповідно до пп. 169.4.1. Податкового кодексу загальну ставку ПСП (50 \% мінімальної заробітної плати на 1 січня) застосовують до доходу, нарахованого на користь платника податку протягом звітного податкового місяця як зарплата (інші прирівняні до неї відповідно до законодавства виплати та винагороди, в т. ч. відпускні й лікарняні), якщо його розмір граничного доходу не перевищує суми, що дорівнює сумі місячного прожиткового мінімуму, діючого для працездатної особи на 1 січня звітного податкового року, помноженої на 1,4 та округленої до найближчих 10 гривень.

ПСП, згідно з пП. 169.2 Податкового кодексу, починає застосовуватися до нарахованих доходів у вигляді заробітної плати 3 дня отримання роботодавцем заяви платника податку про застосування пільги та документів, що підтверджують таке право. Роботодавець відображає у податковій звітності всі випадки застосування або незастосування податкової соціальної пільги згідно 3 отриманими від платників податку заявами про застосування пільги, а також заявами про відмову від такої пільги. Так, загальну пільгу застосовують за одним місцем нарахування (виплати) зарплатного доходу, виключно на підставі поданої платником податку заяви, а для пільг у підвищеному розмірі, передбачених пп. 169.1.2169.1.4 Податкового кодексу, потрібні ще й інші відповідні документи.

Зауважимо, що застосовувати пільгу на двох $\mathrm{i}$ більше дітей, дітей-інвалідів та одиноких матерів (150\% від загальної пільги) одночасно із за- 


\section{ЕКОНОМІКА}

гальною пільгою заборонено.

Таким чином, із нарахованого доходу державного службовця щомісячно утримують четверту частину коштів (податок на доходи фізичних осіб, ЕСВ і добровільні професійні внески). На жаль, «на руки» досліджувана категорія державних службовців Пенсійного фонду отримує близько 180 доларів США (за курсом НБУ 11,7 грн за 1 долар США), що не сягає достатнього рівня.

Відтак одним із суттєвих факторів підвищення ефективності праці державних службовців та основних напрямів реформування державної служби є створення ефективної системи оплати їхньої праці.

Висновки: 1. В Україні доцільно запровадити практику періодичного перегляду системи організації оплати праці державних службовців. Актуальним є врегулювання диференціації заробітної плати державних службовців, яка стосується значних розбіжностей у рівнях заробітної плати різних державних відомств, що знижує мотивацію державних службовців та є способом «переманювання» кращих працівників із однієї структури до іншої. Порядок нарахування заробітної плати державним службовцям в Україні регулю-

\section{БІБЛІОГРАФІЯ}

1. Бюджет 2013: олігархам - все, а народу що залишилось. - [Електронний ресурс]. Режим доступу: http://www.livi.org.ua/2012/12/ zayava_pvk_byudget/

2. Закон України «Про державну службу» № 4050-VI від 17 лист. 2011 р [Електронний ресурс] / Верховна Рада України. - Режим доступу : http://www.rada.gow.ua.

3. Організація державної служби в Україні: теорія та практика : [навч. посібник] / За заг. ред. М. О. Багмета, В. С. Фуртатова, М. С. Іванова. Миколаїв : МДГУ ім. Петра Могили, 2007. 244 c.

4. Пахомова I. Г. Концептуальні засади реформування оплати праці в бюджетних установах України / І. Г. Пахомова, К. В. Лобанова // Вісник Хмельницького національного університету. - № 3. - Т. 3. - 2011. - С. 73-76.

5. Податковий кодекс Ураїни від № 2755-VI від 02.12.2010 р. [Електронний ресурс] / Законодавство України. - Режим доступу : http:// ється занадто великою кількістю нормативноправових актів, що безсистемно визначає всі надбавки.

2. Для врегулювання системи оплати доцільно запровадити посадові оклади, які дадуть можливість довести їхню питому вагу до 50 \% і в цілому підняти заробітну плату державним службовцям на рівень оплати праці в приватному сектоpi. Крім того, система оплати має уніфікувати різницю в окладах і заробітних платах між місцевим та обласним рівнями й рівнем центральних органів виконавчої влади.

3. Спираючись на європейський досвід організації державної служби, виокремимо риси, на які повинна бути зорієнтована вітчизняна модель організації праці службовця: стимулювання виконавської дисципліни державних службовців шляхом забезпечення належних умов їхньої праці, кар' єрного просування, високого соціального рівня; планування, спрямоване на досягнення конкретного результату; контроль з урахуванням якості досягнутого результату; оцінювання персоналу на основі досягнутого результату та індивідуального внеску працівника.

www.nau.kiev.ua.

6. Порядок формування та подання страхувальниками звіту щодо сум нарахованих внесків на загальнообов'язкове державне пенсійне страхування органам Пенсійного фонду України, затвердженого постановою правління Пенсійного фонду України № 22-2 від 08.10.2010 р. [Електронний ресурс] / Верховна Рада України. Режим доступу : http://www.rada.gow.ua.

7. Тищенко В. Б. Особливості організації обліку розрахунків 3 оплати праці в бюджетних установах / В. Б. Тищенко // Управління розвитком. - № 12 (152). - 2013. - С. 73-75.

8. Що стосується заробітної плати. - [Електронний ресурс]. - Режим доступу: http://www. allnews.ua.

9. Щодо пріоритетних напрямів реформування заробітної плати в Україні. - [Електронний ресурс]. Режим доступу: http://old.niss.gov.ua/monitor/ Monitor1_72/01.htm 